\title{
Giving Voice to the Voiceless: Probing Current Issues for Student Teachers in EFL Teacher Education Program in Iran
}

\author{
Fatemeh Karimi, Ebrahim Fakhri Alamdari, Mehrshad Ahmadian \\ Islamic Azad University, Qaemshahr Branch \\ Correspondence concerning this article should be addressed to Ebrahim Fakhri Alamdari, Department of \\ English, Islamic Azad University, Qaemshahr branch, Qaemshahr, Iran. \\ Email: ebrahim.fakhri@qaemiau.ac.ir
}

\begin{abstract}
The present study attempted to give insight into the features of an effective English as a foreign language (EFL) teacher education program by exploring student teachers' beliefs, ideas, and the challenges they encounter during their teacher education program. The data were collected through several semi-structured focus group interview sessions with a total number of forty-one $\mathrm{BA}, \mathrm{MA}$, and $\mathrm{PhD}$ students studying teaching English as a foreign language (TEFL) at university. The qualitative grounded theory design was used to analyze the data, and the findings of the study were corroborated with interpretations obtained from the informal observation of several university classes in a TEFL teacher education program in Iran. The inductive analysis of the data resulted in developing the following categories: the challenge of developing the ability to move back and forth from theory to practice,the struggle to establish a professional identity, the quest for the 'self', less-practiced reflective practice, and the missing connection between teacher education programs and schools. The discussion concerning the challenges and issues culminated in implications for EFL teacher education programs through which they can take the issues that student teachers normally experience into account and help them pave the way for an effective EFL teacher education program.
\end{abstract}

Keywords: teacher education, student teachers, English language teaching, beliefs, identity, theory and practice

\section{Introduction}

Language teacher education programs are designed worldwide to comply with criteria and benchmarks for language pedagogy assigned by education decision-makers and the administrations of the respective contexts. Hence, a variety of location-specific language teacher education (TE hereafter) programs have been designed worldwide. Recently, the underlying assumptions of language TE have been critically examined by some scholars and researchers in order to analyze the components, investigate the outcomes of current TE practices (e.g., Ganji et al., 2018, Johnson, 2015), and propose the features of effective teacher preparation programs (e.g., Brooks \& Darhower, 2014; Huhn, 2012; Johnson, 2006). Globalization and its impact on education regarding the system, policies, programs, curricula, and students in TE programs (Paine, 2019) have arisen the need for the emergence of shifts in the traditions of foreign language learning and teaching, and this basically requires restructuring and rethinking of TE assumptions (Kumaravadivelu, 2012).

In their attempt to investigate the features of an effective TE program, scholars discussed the unhelpfulness of top-down models to TE. They suggested a shift from the process-product approach (Freeman \& Johnson, 1998) and TE's transmission-based models (Kumaravadivelu, 2008). Recently, the cognitive processes of student teachers (STs hereafter) on their way of becoming teachers are being acknowledged, and the effectiveness of approaches that encourage STs to reflect on their own teaching is being recognized (Geyer, 2008). With interest in the inquiry-oriented approach to TE, teacher development is now being considered concerning cognitive, social, and contextual views (Darling-Hammond, 2006; Huhn, 2012; Johnson, 2006). Additionally, models of TE that pay attention to the importance of teachers' cognition, reflection, and personal visions and versions of teaching are being acknowledged (Kumaravadivelu, 2008). 
Teacher cognition is concerned with "what teachers know, believe, and think" (Borg, 2003, p. 81), and research on teacher cognition aims to reveal the invisible dimensions of teaching (Borg, 2009) by understanding teachers and their act of teaching. Reflection is a crucial means of understanding teacher cognition. Reflecting on teaching contributes to teachers' understanding and recognizing their identity and 'self' as teachers. Beauchamp and Thomas (2009) believe that one of the ways of defining identity is to understand "the responsibility of TE programs to create opportunities for the exploration of new and developing teacher identities" (p.176). Scholars have asserted TE's role in forming identity; nevertheless, to the present researchers' knowledge, only a few empirical studies have been conducted to support this hypothesis (e.g. Schepens et al., 2009).

Recent research in TE recognizes the importance of exploring teachers' cognition and beliefs to better understand the act of teaching and the way teacher identity is shaped or developed during TE programs (Fairley, 2020; Korthagen, 2004; Walkington, 2005;). However, the existing literature, to the present researchers' knowledge, has not paid enough attention to STs' beliefs regarding the TE programs they participate in. The process of designing a TE program that suits foreign language teachers' needs begins by knowing and analyzing the current issues and shortcomings. Teacher educators are able to meaningfully and effectively guide STs if they understand the challenges STs are faced with during teaching practice and the strategies they adopt to deal with those challenges (Foncha et al., 2015). Additionally, examining the existing issues in TE programs results in rising awareness among both teacher educators and EFL teachers about misleading language learning and teaching assumptions (Hedgcock, 2002). In fact, teacher development and student achievement are directly connected to TE programs (Darling-Hammond \& Youngs, 2002). Recently, with the increasing demand for English language learning and teaching at individual and national levels in Iran (Sadeghi \& Richards, 2016), Iranian state and private universities hold EFL TE programs at undergraduate, graduate, and post-graduate levels. However, despite the inclination toward a reflective inquiry-oriented approach to TE in other countries, teacher preparation program offered by Iranian universities, mostly, design their curriculum according to transmission-based models (Safari \& Rashidi, 2015). Therefore, based on the beliefs of some STs, the present study aimed to explore the issues and challenges that they commonly encounter during TEFL teacher education programs in Iran. In this vein, this study first describes the context of current TEFL teacher education programs (see the Context section) in Iran; then by probing into STs' perceptions, it examines the existing issues for STs during their TE program. Raising this awareness seems to be of importance to curriculum designers who make decisions about the courses and the program, teacher educators who are required to develop autonomous teachers, and finally to STs who are being prepared for classroom instruction.

\section{Background}

For a long time, English language TE programs have been inclined to orient the programs based on a rationalistic model (Day, 1993), or applied science mode (Wallace, 1991). Grounded in a positivistic paradigm (Geyer, 2008), in this top-down model, teacher development revolved around learning the prescribed knowledge and content and the prerequisite methodology needed to teach the content (Richards, 2002). The process of teaching was believed to result in the product of student learning and any failure in the product questioned teachers' competence in the teaching process (Freeman, 2002). Following a predetermined curriculum and incorporating a static view of teaching (Richards, 1990), transmission-based TE programs are oriented toward the transfer of specific contents and knowledge as well as prescribed methodologies to STs, neglecting the context and STs' involvement and autonomy (Kumaravadivelu, 2012). This technicist approach, through which theories produced by scholars are presented through a number of isolated courses without illuminating their connection to practice, results in the gap between theory and practice (Korthagen, 2010). Within the context of EFL teacher education in Iran, where TE programs generally design their curriculum based on transmission models of TE (Safari \& Rashidi, 2015), STs and teacher educators are asking for more practical courses such as practicums and classroom observations to be included in the program and help empower STs as they attempt to overcome the realities of classrooms (Gholami \& Qurbanzada, 2016).

The long-established behavioral conceptions of teaching have recently given way to the views adhering to sociocultural theory (Johnson, 2006). Socio-cognitive views of teaching consider teachers to be social beings who bring with them the life experiences of their own teachers and teaching acts to TE programs and admit that teachers' beliefs shaped by their past experiences influence their present act of teaching (Borg, 2006; Korthagen, 2004; Richards, 2002). Additionally, as learning to teach requires assistance, it is through dialoguing 
and collaborating with others that STs learn to teach (Johnson, 2009). Therefore, the socio-cognitive perspective gave ground to an inquiry-based approach to TE by highlighting teachers' cognitive processes of learning, teacher beliefs, and teacher reflections, all of which show both the current and developing abilities of STs (Borg, 2003; Burns \& Richards, 2009; Johnson, 2009; Richards, 2002).

Through an inquiry-based approach, major research areas have been significantly and comprehensively developed, promoting the importance of teachers' mental lives and their impacts on teachers' teaching and decision-making processes. Existing research has addressed the leading role teachers' cognition and beliefs play on different aspects of their teaching (e.g. Borg \& Al-Busaidi, 2012; Phipps \& Borg, 2009), and it has highlighted the role of TE in raising awareness among STs regarding the importance of knowing and recognizing personal experiences, beliefs, and reflections as well as their potential effects on their teaching (e.g. Deberli, 2012; Mattheoudakis, 2007). By helping teachers to know who they are as teachers and by examining different aspects of teachers' teaching, research on teacher identity "as an analytic lens" (Beauchamp \& Thomas, 2009, p.175) has been considerably highlighted in TE (e.g. Bukor, 2015; Schepens et al., 2009; Søreide, 2006). However, only a few studies have investigated the role of TE in developing teacher identity in Iran. Zare-ee and Ghasedi (2014) explored EFL prospective teachers' issues in constructing professional identity at the undergraduate level. A lack of support from administration, class sizes, and instructional methods were reported to be major blocks for professional identity development. As reported, STs require TE to equip them with up-to-date teaching techniques and materials to become able to design and use modern English language teaching (ELT) materials. While examining the identity conflicts that EFL teachers encounter, Eslamdoost et al. (2019) found that, considering the highly centralized ELT programs in Iran, conflicts mostly arise from contrasts between EFL teachers' personal ideologies and the regulations assigned by the authorities both at the language institutes and at the national level. Thus, TE is recommended to prepare STs to confront these conflicts.

Recognizing teachers' cognition, beliefs, and eventually the way they establish their professional identity is the concern of TE's exploratory models that aim to develop autonomous teachers, reflective practitioners, and theorists who can create context-specific procedures for their classrooms (Kumaravadivelu, 2012). Such programs involve reflective practices by which teacher educators ensure that STs gain the necessary knowledge base, and evaluate and reflect on their own practice (Day, 1993). Generally, now, TE is recommended in order to take a cyclical holistic approach that neglects top-down exercises and focuses on developing strategic thinkers and explorers who construct their own insights and versions of teaching (Kumaravadivelu, 2001). Adopting this constructivist orientation, Abednia (2012) documented the contributions of a critical EFL teacher education program to the professional identity reconstruction of Iranian teachers who, through the program, shifted from compliance with dominant ideologies to critical autonomy, from an instrumentalist orientation to a transformative orientation of teaching, and from a linguistic and technical view to an educational view of foreign language education. Tajik and Pakzad (2016) put the assumptions of reflective teaching in practice by designing a reflective TE course and documented the positive contributions of this course on STs' reflectivity. However, TE that is required to be the origin of reflective practice may act as a barrier for implementing the exploratory models of TE due to the strong roots of long-lived traditional practices (Safari \& Rashidi, 2015).

Despite the emerging inclination of Iranian researchers to evaluate various TE programs, mostly the ones held as teacher training courses at private language institutes (e.g. Ganji et al., 2016; Tajik et al., 2019), EFL student teachers' beliefs, concerns, and issues encountered during and after the TEFL program that they participate in at a degree level at university have not received much attention. The present study aimed to address this gap in the literature. By observing and understanding the way STs perceive their program and by highlighting the issues that Iranian EFL teachers deal with when studying TEFL and after graduation, the present study attempts to enlighten the way toward an effective TE program, one that includes the components that STs acknowledge a need for and helps eliminate the problematic issues that act as obstacles to the development of autonomous EFL teachers.

\section{The Context}

English language TE programs are held in various contexts in Iran. The institutions holding these programs include language institutes, universities directed by the Ministry of Science, Research, and Technology, universities regulated by the Ministry of Education, and private university systems such as Islamic Azad University certified by Supreme Council of the Cultural Revolution in Iran. Universities offer English language 
TE programs at three levels of Bachelor's, Master's, and Doctoral degrees. The program for each level of university degree is briefly described below.

Generally, TE programs for BA students take nearly eight semesters to be completed. The first four semesters are focused on developing general English skills and knowledge of language components. During the next two years, STs take part in various courses, including teaching methodology, research methodology, materials development, practical teaching, testing language and assessment, linguistics, and translation. Of course, every university curriculum offers its own arrangement of courses, but all universities include the abovementioned courses in their EFL teacher education programs. The English language teaching (ELT) graduates are expected to be prepared to teach the English language at schools or language institutes.

The curriculum for an MA degree in TEFL is a full-time two-year graduate level program. The curriculum includes required courses on language teaching methodology and principles, language skills teaching methodology, materials development, research methodology, language testing and assessment, and a seminar course. Additionally, there are a variety of elective courses that each university offers during TE program; such as courses on linguistics in teaching language, academic writing, discourse analysis, English for specific purposes, and technology-enhanced language teaching/learning. The fourth semester onward is devoted to research. The MA graduates in TEFL are expected to have developed the necessary skills to function effectively as classroom teachers and be prepared to teach language at schools and language institutes.

The Doctoral of TEFL is a full-time minimum four-year graduate level TE program. During the first four semesters, STs participate in required courses such as research in language education, language assessment, second language acquisition studies, language curriculum development, and critiques of issues in language teaching. Elective courses include courses on sociolinguistics, psycholinguistics, first language acquisition studies, English for specific purposes, language teacher education, and some other courses that are specific to the curriculum of each university. The next two years or more are devoted to academic research. The PhD graduates in TEFL have the opportunity to work as instructors at universities, schools, and language institutes. In addition, they are expected to be qualified enough to work as teacher educators at schools, universities, and language institutes. They could work in both academic and research positions. However, it should be noted that the job opportunities available at public schools and state and private universities for language teachers and teacher educators are to be filled by the most qualified candidates after a selection process.

\section{Materials and Methods}

\section{Research Design}

Due to its exploratory nature, grounded theory was used in the present qualitative research (Corbin \& Strauss, 2014). The questions that led to us conducting this study were the problems found according to prior research (e.g., Gholami \& Qurbanzada, 2016; Safari \& Rashidi, 2015) and the personal experiences of the researchers. Discovering teachers' ideas, concerns, and beliefs in TE programs required an inductive approach to data collection and analysis, and grounded theory helpfully contributed to generating categories and themes (Corbin \& Strauss, 2014) of ideas and beliefs. Within this framework, the researchers selected semi-structured focus group interviews and informal observation -including visits to some ELT-related courses- as the data collection techniques, all of which provided a more profound understanding of the present issue. The data collected through interviews and informal observations were inductively analyzed since no predefined themes according to the objectives of this research had been previously provided. Thematic analysis and coding were the two procedures that contributed to the extraction of the themes, categories, and thoughts.

\section{Participants}

Purposive sampling was employed in order to collect data from the individuals who suit the problem under study and provide rich information regarding the topic of the research. The participants of the present study were 41 STs studying at either public or private universities in order to achieve BA, MA, or PhD degrees. The BA participants were 17 senior STs studying either English Language and Literature or English Language Translation. It is worth noting that both majors have nearly similar curriculums regarding the courses related 
to English language teaching. Since not all BA students had teaching experience, the researchers conducted separate interview sessions with experienced and non-experienced students. The rationale for this division was that the researchers assumed that the factor of teaching experience might influence STs' ideas and beliefs about the TE program.The MA participants were 14 students, and the $\mathrm{PhD}$ participants were $10 \mathrm{STs}$ studying TEFL at university. All MA and PhD participants had prior English language teaching experience and they were in the third semester of the respective degree levels, after which they will finish studying their educational courses and begin writing their theses and dissertations. The researchers intentionally selected senior students of each degree level since they believed senior students had passed enough time and courses at university to (re)shape and (re)form ideas and beliefs about their TE program. As a matter of confidentiality in using and analyzing the data, the researchers assigned a number to each of the 41 participants. Then, the participants of each degree program were distinguished by adding the name of the degree level to the assigned number, for example BA1, MA18, PHD35. Numbers were assigned from 1 to 41 i.e. the total number of participants. The details of the participants are indicated in the Appendix.

\section{Data Collection}

The data collection of this study began by selecting two universities as the context of the research in which the observations and focus group interviews were conducted. Both selected state and private universities held similar required courses for BA, MA, and PhD students in TEFL. With prior coordination with the respective department, the two authors of this study, who are also faculty members, arranged focus group interview sessions with senior students. By providing a natural and real-life environment, focus group interviews encourage the participants to discuss the issue of interest, although it is possible that participants' ideas and beliefs may have an effect on the others' ideas and beliefs during the discussion(Casey and Krueger, 2000). Focus group interviews suited the purpose of this study as related to the planning, improvement, and evaluation of TE programs. In addition to conducting focus group interview sessions, the two faculty members provided the opportunity for the other author -who is a PhD candidate in TEFL, to attend and observe a session of an ELT-related course for each group of participants in order to gain a better understanding of the present situation and to learn about the activities of the people under study in their regular context (DeWalt \& DeWalt, 2010). After observing a class for each degree level at both universities, the researchers conducted group interview sessions with senior students. At the beginning of the session, the researcher explained the aims of the study to the participants, asked their permission for audio recording the session, and assured them that all data would be used anonymously for writing an academic research paper. Each group interview lasted for 60 to 90 minutes. STs were free to state their ideas in English or their native language. i.e., Farsi. Totally, eight sessions of group interviews with each session devoted to a specific degree level were held in the selected universities. Four interview sessions were allocated to students at one university, and the other four sessions were devoted to the second university's students. As a facilitator, the researcher initiated the focus group interviews and explained the aim of the discussions. Next, she asked questions designed to elicit the participants' ideas, insights, beliefs, and issues that they normally struggle with during their TE program. Every individual had enough time to share ideas and beliefs. At the end of the sessions, the researcher reviewed the key points discussed during the session in order to summarize the main ideas that were mentioned and ask the participants to add any additional points they may have.

\section{Data Analysis}

Following the grounded theory framework, the data analysis was done through the inductive analysis of the contents and, accordingly, a sequential coding system (Dörnyei, 2007). The data included the precise transcription of semi-structured focus group interviews, done by one of the researchers and checked by the other two researchers. Furthermore, the notes and journals that one of the researchers collected while observing several BA, MA, and PhD ELT-related courses that the participant STs attended were shared and discussed with the other two researchers during some debriefing sessions, and the ideas and reflections were later used as memos while interpreting the data. The process of inductive data analysis requires deep and precise (re)reading of the interview transcriptions. Next, having taken the first steps of the data analysis, the researchers segmented the contents into instances of issues and challenges that STs encountered during their TE program. The chunks' length varied between phrases, sentences, or short paragraphs, which represented the problematic areas STs faced. Then, the segments were labeled and, later, the ones with similar concerns were colored the same and classified under their relevant category label. In the next step, the researchers scrutinized 
the textual data to find connections between the categories with a similar focus in order to integrate and group them under a relevant category. Being actively engaged with the data during the process of data analysis, the researchers used memoing to note the ideas and thoughts that were related to the data. The journals and notes collected during informal observation sessions were also used as memos for facilitating the process of coding and interpreting the data. In this way, the categories that emerged from the interview transcriptions were integrated and corroborated with the data collected through the observation sessions. In the last step, the relationships and connections between the perceived categories were explored and this resulted in developing some core categories on which the researchers concentrated in writing the study. The core categories are discussed in the findings section. The process of data analysis is illustrated by the following example. The researchers found various instances related to many theoretical courses held during the program, the lack of practical courses, and being unable to put theory to practice in a real classroom, and other similar instances that were categorized under the label being unable to relate theory to practice. Then, there were instances such as no opportunity to share personal teaching experiences, a few opportunities to discuss and receive feedback regarding the methods that STs find effective, and other similar points that were categorized under the label failure to develop the ability to theorize practice. These points asserted by participant STs were corroborated with the journals written during the observation sessions, as the researcher perceived that the university courses are mostly theoretical, including monologue lectures by the instructors. Then, these two categories were condensed into one major category labeled as the challenge of developing the ability to move back and forth from theory to practice, which is discussed in the Findings sections. Accordingly, open coding, axial coding, and selective coding were used in this grounded theory method of data analysis (Dörnyei, 2007). The analysis performed by one of the researchers was reassessed by the second and the third researchers of this study in order to enhance the reliability of the findings. Additionally, (re)reading and reviewing the transcriptions and reports, recording the interviews for audit, and using focus group interviews and observations for collecting accurate data contributed to the dependability of the findings. The credibility of the findings, or triangulation (Shenton, 2004) was assured by gaining various insights from different STs regarding the issues of the research and corroborating the findings with reflections from the observation sessions. The researchers attempted to assure the transferability and confirmability of the findings by providing detailed descriptions of the context, and the steps taken in data collection and analysis.

\section{Results}

The data analysis process resulted in developing five categories that will be discussed throughout this section and extracts from the data are presented to illustrate the categories. Please note that although the categories that emerged from the data were obtained from the participants of the three degree levels, the researchers have not discussed them in separate sections for each degree level since the ultimate goal of the present study was to explore the features of a comprehensive TE program in the view of STs and those essential features could not be devoted to one specific degree level.

\section{The Challenge of Developing the Ability to Move Back and Forth from Theory to Practice}

All participant teachers of this study acknowledged the number as well as the availability of courses and resources allocated to presenting theories of language pedagogy. The theoretical courses arranged to cover the essentials of the field were reported to be adequate to meet the STs' needs for learning the required theoretical knowledge. Relating the presented theories to practice, however, was what participant teachers considered to be a very challenging task. One of the BA students with no teaching experience said:

All we have learned is through our ears. I mean we do not see any practical teaching, we just hear about how to teach (BA7).

Without seeing and engaging in practical teaching, learning to teach, as another BA student with teaching experience said, is:

...similar to learning to repair cars just by reading the related books and not by practicing actual repairing (BA 13).

All BA students felt the need for including practical courses on language teaching in the curriculum. In fact, as the abovementioned excerpts indicate, this need was greatly highlighted by BA students who are at the 
beginning of the road to becoming teachers. They demanded either including practical teaching courses in the TE curriculum, or asked for opportunities that the program could arrange for them to visit experienced teachers' classrooms. Gholami and Qurbanzada (2016) addressed the same issue in their research as they found that STs wish to have more practical aspects included in the program. Accordingly, the STs of the present study highly demanded a situation through which they could see the link between theory and practice and the way those could be connected. While BA students searched for teaching role models and the actual practice of the theories they were learning, the MA and $\mathrm{PhD}$ STs, in a more professional discussion, asserted that practical teaching courses reveal the applicability of language teaching methods and language pedagogy theories in their specific context. The following extract depicts this point:

To my experience, methods have been prescribed for ideal situations. As a teacher of a public school, sometimes, the number of students exceeds 40 in my classes. Students are all different in terms of motivation and attitude towards language learning and many other personal factors. In such situation, how can I manage to apply prescribed theories? (PhD34)

Most graduate students believed that for methods and theories to be employed, many factors need to be considered, factors such as the size of the class, the age range of the students, their level of language proficiency according to their prior language learning experience, and the facilities and technologies that are at hand in that specific context. Participant teachers of this study noticed the challenge of relating learned theories to real practice and, as one of the MA participants asserted, they believe that:

\section{If teachers fail to find the link between the instructed theories and the real situation, they may avoid considering and using them (MA29).}

Although scholars believe that effective qualified teaching needs to be rooted in sound and established theoretical foundation (Higgs, 2013), the findings illuminate that TE programs may not act effectively in preparing teachers for realities of the classroom. This gap between the theories and practice has been asserted by various scholars (e.g. Hennissen et al., 2017; Korthagen, 2010).

Furthermore, the STs asked to be given 'voices' during the TE program. As a one of the BA students with teaching experience asserted:

Most of our classes involve monologue lectures of instructors. We like to add the flavor of personal experiences to the courses and ask for ideas (BA11).

The 'voice' that STs asked for, in their view, is a sign of how they value the personal experiences of their teacher educators. In fact, teachers' experiences, either as language learners or teachers, influence their beliefs about learning and teaching and, accordingly, beliefs strongly influence teachers' methodologies of teaching and direct teachers' acts in the classroom (Korthagen, 2004). The STs asserted that having a voice empowers them with the independence and authority to acknowledge their effective teaching experiences and to theorize their practice. It gradually assists them to develop professional agency in order to become active agents of their profession (Yangın Ekşi et al., 2019)

\section{The Struggle to Establish a Professional Identity}

The STs' beliefs about themselves can lead them to construct their identities, especially professional identities (Korthagen, 2004). Individuals as agents construct identity within a specific social, cultural, historical, and political context (Aneja, 2016). Hence, identities are multiple and dynamic and they change and develop through time and space. Participant teachers believed that TE programs are greatly concerned with covering course syllabi and that the reality of teaching in classrooms is not vividly discussed. Professional identity, according to Beijaard et al. (2004) consists of sub-identities that may conflict with each other during TE programs and real classroom practice. For instance, the ideal teaching situation pictured in theories may be different from the reality of workplaces. This conflict of workplace issues as an aspect of professional identity was felt by participant teachers. One of the MA students depicted this issue:

We have to work within the limitations of a customer-oriented system which is far from what is learned from theories (MA19).

Referring to giving priority to customers' demands in private working environments, a $\mathrm{PhD}$ student asserted: 
The scores that are obtained from exam papers of language learners are the measure of teachers' competence. The higher the scores, the better the teachers are assumed to be. Such product-based view ties teacher's hands (PhD39).

Furthermore, graduate STs believed that being full-time students, having low incomes during their education, costs of university enrollment, and considerably high workloads were among other impediments to professional identity development. Apparently, TE programs have failed to develop autonomous teachers who are empowered with the tools to overcome the constraints of administrations, institutes, and textbooks (Kumaravadivelu, 2001). Domains of professional identity such as student needs, workplace issues, and personal development need to be considered by TE programs. The impact of TE programs on the professional identity development of teachers has been the concern of several researchers (e.g. Bukor, 2015; Nickel \& Zimmer, 2019). With regard to the role of context in forming identity (Beijaard et al., 2004), they recommend that teacher educators offer teachers the opportunity to negotiate their personalities in order to discover multiple identity possibilities, each to be used in its own proper right (Aneja, 2016).

\section{The Quest for the 'Self'}

The participants of this study believed that being exposed to a bulk of information through merely monologuebased instruction from teacher educators as well as the lack of opportunities for the involvement of STs in expressing their related experiences and beliefs caused the STs to find it difficult to answer the questions about who they are and what kind of teacher they are going to become. While professional identity refers to a set of characteristics attributed to an individual by society in a way that they are recognized for that identity, the 'self' refers to an individuals' sense of asking who am I and what am I. Being aware of the importance of knowing their 'self', participant teachers recommended 'experience sharing' (BA9, MA25) as an advantageous act that enables them to:

...compare out teaching act to what is shared by our classmates (BA2)

...understand the positive and negative points of our teaching and receive helpful feedbacks from our teachers and classmates (BA14)

...learn ways of getting to know ourselves as teachers of our own class (MA22)

It seems that the courses arranged for the BA level in TE programs are merely concerned with the knowledge of language and some introductory courses to generalities of English language pedagogy. The issues of selfknowledge, identity formation, critical thinking, and reflection appear to be highlighted in the graduate-level curriculum. This gap was revealed clearly when the present researchers inquired about recommendations for better TE programs and the BA students merely asked for more courses on developing the speaking skills. Although the BA students defined knowledge of the 'self' in terms of their language proficiency, the MA and $\mathrm{PhD}$ students had a deeper understanding. In some cases, they blamed TE for not paying enough attention to this issue, and in some other instances they believed that teachers were responsible for promoting their own knowledge of the 'self'. The following example extracted from a PhD participant depicts this issue:

Sometimes, teachers themselves do not feel the necessity of gaining self-knowledge and they do not observe their attitude as teachers, their achievements, and received feedbacks (PhD32).

As pointed out by participant teachers of this study, there are several factors that hinder teachers in the journey of learning to know their 'self'. Highlighting the importance of the issue, sharing experience, receiving feedback, and feeling the inherent need for gaining self-knowledge are among the factors that pave the way for teachers to know their 'self'. Korthagen (2004) asserts that deep in teachers' minds, there are questions related to the meaning of existence within a larger community and such questions may have a religious nature of commitment to environments and ideals. This level of self-knowledge is something not all STs are equally aware of (Korthagen, 2004). However, as Crooks (2015) claims, rationalizing teachers' practice requires an understanding of their philosophy of teaching, which is rooted in their personal experiences, values, views, and reflections of the world.

\section{Less-Practiced Reflective Practice}

Today, in the era of technology and information, teachers need to be equipped with the knowledge and skills necessary to overcome the needs of students in a globalized society. In such a system, teachers should be 
reflective thinkers, strategic teachers, and researchers. The participant teachers of the present study felt the necessity to develop as reflective teachers and researchers who actively seek up-to-date knowledge. The following example from an MA student shows this concern:

In the era of information and communication, teachers should take less pride in what they already know and should constantly search for knowledge and look for improvements (MA31).

In their own situation, as STs participating in TE programs, STs required an inquiry-based curriculum. TE programs need to develop a curriculum that is focused on reflective practice and highlights the importance of self-observation and self-evaluation. The following examples given by $\mathrm{PhD}$ participants depict this issue:

Teacher education programs should develop teachers who have critical insight and deep analysis of themselves, students' feedbacks, materials, teaching environment, and what happens around (PhD36).

Such reflective program makes the teacher 'feel the necessity' for a change in her teaching. Without this feeling, a teacher may follow the same route for years despite being questioned by supervisors and observers (PhD32).

As illuminated, STs require opportunities to participate in a system that encourages teachers to think and analyze. It seems that TE programs occupied with transmitting information and theories to STs have not been successful in designing reflective curriculums and developing reflective teachers. According to Akbari (2008), there are several barriers to employing reflective practice as the outcome of postmethod pedagogy in the Iranian EFL context: a) the top-down and administrative system that does not leave room for teachers' autonomy to develop, b) the lack of time, resources, and willingness to implement postmethod pedagogy on the part of teachers, and c) requirements for postmethod pedagogy need daring teachers to implement such pedagogy that, as a result, could lead to their isolation from their discourse community.

\section{The Missing Connection between Teacher Education Programs and Schools}

School teachers already graduated from university work under the supervision of Ministry of Education and need to comply with the rules of national documents that set educational policies. Since the intensive curriculum of TE program under the current circumstances may not leave room for including more practical courses, the participants of this study recommended making a connection between TE programs and schools as a solution. Experiencing the difficulties of being novitiate, STs:

....are willing to spend apprenticeship periods at schools, preferably the schools that are linked to the TE program we participate in (BA15).

In this way, not only do STs become experienced in teaching real classes, but they also become acquainted with the regulations of the schools. By providing this opportunity, STs believed that the school and the program would take the same path toward teacher development; otherwise, teachers could find it hard to counterbalance what they have learned during the program and what schools require them to do. Participant STs expressed some of the challenges they confront while teaching at schools. As one of the BA participants said:

The ideal situation of teaching pictured during teacher education program is very different from the reality of teaching in the class. At workplace, we face issues related to students, families, school principal, observers, supervisors, rules, and regulations. We have not been prepared for this. (BA5)

Considering the adequate theoretical courses held in teacher education program, STs asked to be provided with ways to adopt theories in various contexts. One of the $\mathrm{PhD}$ STs asserted:

Teacher educators need to consider the differences among various ELT contexts and prescribe solutions accordingly. (PhD40)

Teachers appear to find it challenging to put what they have learned during TE programs into practice. There are several factors that cause this discrepancy. Mirhosseini and Khodakarami (2016) investigated the covert and overt ELT policies in the Iranian context and found the missing links in ELT policies to be "constructing coherent ELT policies; creating awareness regarding the ideological nature of ELT; and communicating the logic of official policies to frontline practice contexts" (p. 295-6). Therefore, it is recommended that TE programs raise awareness in STs regarding the national educational policies in order to hinder the conflicts that STs confront during real teaching practice. 


\section{Discussion}

TE programs can play a pivotal role in preparing teachers and developing their skills. Due to the limitations when fostering teachers' requirements and preparing teachers to meet learners' needs in some long-established models of TE, the present study, although limited in its scope, attempted to illustrate the components of an effective TE program by understanding the beliefs and ideas of forty-one participant STs attending TEFL programs at $\mathrm{BA}, \mathrm{MA}$, or $\mathrm{PhD}$ levels at two universities through semi-structured focus group interviews supported with interpretations gained from visiting several ELT-related courses in the same universities. Using a grounded theory research design, the inductive analysis of the data resulted in the development of the following categories: the challenge of developing the ability to move back and forth from theory to practice,the struggle to establish a professional identity, the quest for the 'self', less-practiced reflective practice, and the missing connection between teacher education programs and schools.

Relating theories to practice was viewed as a challenging task by the STs. Mostly, the STs viewed TE as a theoretical curriculum that fails to simulate the classroom's spontaneity or the reality of the workplace (Walkington, 2005). This issue results in the gap between theory and practice (Korthagen, 2010). Therefore, the STs expressed a desire to attend more practical courses during their TE program in order to become prepared for the realities of the classroom and learn how to put the theories into practice. In line with this finding, Gholami and Qurbanzada (2016) asserted that STs and teacher educators acknowledge the need to include more practical courses such as practicums and classroom observations into their programs. The participant STs recognized the value and importance of knowing theories; however, they wanted more involvement in the way theories are presented in order to explore the ways theories could be implemented in real practice. Sjølie (2014) asserted that the way STs conceptualize theory can affect the way they engage with the theories in their TE courses. According to the participant STs, illuminating the role of theories in practice requires the guidance of teacher educators in order to help the STs learn from both the theories and practice. As Gholami and Qurbanzada (2016) explained, the courses in which their practicality is not clear to student teachers are considered to be unhelpful in preparing them for real teaching.Teacher educators are recommended to have open ears regarding STs views and ideas in order to understand how to present theories (Sjølie, 2014). On the other hand, teacher educators need to be equipped with more theoretical knowledge and ability to connect theories to their students' future practices, as well as their own (Swennen et al., 2008).

Teachers greatly acknowledge their personalized beliefs about learning and teaching. The established beliefs work as filters that direct the way future teachers perceive and interpret the information presented to them through TE programs (Borg, 2006). Therefore, as mentioned by the participant STs, teacher educators need to value the personal experiences and beliefs of STs and help them become more involved in their education programs (Wilks et al., 2019). They also give STs the 'voice' to share their pedagogical concepts and teaching principles arisen from their personal experiences in order to help them overcome teaching difficulties. Similarly, Tajik and Pakzad (2016) asserted that giving STs a voice to express their thoughts in the class contributes to teachers' reflectivity. Guided by teacher educators, STs may benefit from observing and analyzing their teaching and become empowered to theorize their own practice. Furthermore, as Pajares (1992) suggested, preservice teachers tend to preserve their pre-existing beliefs unless those beliefs are proved to be unsatisfactory and inadequate by being challenged. A reflective approach provides a thought-provoking situation through which STs could verify their assumptions and knowledge of language teaching and learning (Farrell, 2018).

Notwithstanding the main focus on covering the theoretical syllabi and reduced emphasis on practical teaching and personal experiences in the current TE programs, STs, struggling to establish a professional identity, are actively seeking professional development in order to reach their goals. As Zare-ee and Ghasedi (2014) asserted, TE could greatly support STs in developing a professional identity; however, the lack of support from the administration acts as a major block in ST's professional identity construction. TE programs should be required to empower STs with the tools to overcome the constraints imposed on them by workplace, materials, and administration. In agreement with this finding, Abednia (2012) found that critical TE helps STs develop critical autonomy since critical TE enables STs to reconsider their uncritical habits and attitudes and become aware of the constraints imposed on them by authorities and institutions. In helping STs to construct professional identities, TE is recommended as a way to provide the opportunity for teachers to negotiate their personalities in order to discover multiple identity possibilities, each aimed to be used in its own proper right (Aneja, 2016). Teachers consider the identity construction built upon negotiation and positioning as a relevant and meaningful 
experience (Søreide, 2006) which helps them deal with aspects of professional identity such as learner needs, workplace issues, and personal development.

TE programs are advised to highlight the importance of helping STs gain self-knowledge since the beliefs that are shaped in the familial environment of teachers can influence their experiences at school, as well as their career choices, teaching practices, teaching philosophies, and teacher identities (Bukor, 2015). As discussed by the participant STs, their program may contribute to self-knowledge development by creating a situation in which the STs could share related personal experiences, receive feedback, and inherently feel the need to gain knowledge of the self. Through reflective activities, teacher educators can assist STs by challenging their personal experiences and beliefs (Walkington, 2005). On that account, with the competence and confidence obtained from reflective practices during their program, STs autonomously become the decision-makers in their own classes and develop into the professional agents of their careers (Yangın Ekşi et al., 2019).

The interviews with the participant STs documented their inclination to participate in a reflective curriculum which, despite the limitations imposed on them by their administrations and materials, develops in them the ability to think, analyze, reflect, make decisions, and inherently feel the necessity to make a change. In line with this finding, Abednia (2012) found that critical TE helps STs to shift their views from thinking of teaching as an instrument, which deprives teachers' freedom of action and thoughts, to the view that they could transform the present situation by raising awareness and making a change. Although there are barriers to the implementation of reflective practice in the Iranian EFL context (Akbari, 2008), Tajik and Pakzad (2016) encouraged reflective practice in TE by familiarizing STs with types of reflection, giving them opportunities to internalize reflection types through action, encouraging STs to share ideas with colleagues, and practicing selfinquiry.

The present study found some inconsistencies among national ELT educational policies, the theories taught in TE programs, and the real-life practices of English language teaching. Therefore, it is recommended that TE programs invest more time in raising STs' awareness regarding the logic of national educational policies (Mirhosseini \& Khodakarami, 2016) in order to limit the conflicts that STs encounter during real teaching practice due to the contrasts between teachers' personal ideologies and regulations assigned by authorities (Eslamdoost, et al., 2019). Furthermore, as mentioned by the participant STs, considering the location-specific requirements of each ELT context (for example, language institutes or private and public schools in rural and urban areas), teacher educators should prescribe proportionate guides that fit the situation. Mentors and teacher educators are required to have an accurate understanding of the specific ELT situation for which they are preparing teachers. Additionally, by maintaining the link between TE programs and schools, STs may obtain the needed assistance, exchange experiences, and explore the link between theory and practice (Kimmelmann \& Lang, 2019).

\section{Conclusion}

Based on the beliefs of a number of STs, the present study aimed to explore the issues and challenges that they commonly encounter during TEFL teacher education program in Iran in an EFL context. The findings of this study were obtained from a qualitative research design that inspected the particular characteristics of a specific context. However, the results of the present study may have implications for both local and foreign contexts. As mentioned in the context section, the curriculum of every degree level at university prepares STs to teach English. Since not every BA student teacher may enter a graduate program, TE programs need to raise BA students' awareness concerning self-knowledge, identity formation, critical thinking, and reflection. As STs' beliefs regarding TE programs for each degree level at university seem to be neglected in the literature, the results of the present study may be thought-provoking for scholars and teacher educators as they discover what STs think of their TE programs due to the fact that teachers' beliefs and cognition greatly influence their teaching act. Additionally, the ST's desired components for TE discussed in this study may be of use to curriculum designers and material developers so that they can design programs that pay more attention to STs' needs.

Overall, taking the first steps toward proposing the components of an efficient university TE program in light of STs' perceptions in the Iranian EFL context, the researchers found that by involving STs in the curriculum 
and fostering their autonomy, TE programs can develop language teachers who are empowered with the essential competence, confidence, and tools to teach and make decisions in their classrooms. Teacher educators may develop STs' identities by guiding them to reflect on personal beliefs and experiences in the context of TE programs and workplaces, and the roles they play within each context. By engaging in reflective activities and receiving feedback, they can find the connection between theory and practice, and consequently, find the 'voice' to theorize their practice. TE programs need to help STs discover insights about their beliefs, perceptions, and interpretations rooted in their personal, educational, and professional experiences, all of which can greatly influence teacher identity. Fostering STs' autonomy can prevent teachers from simply adapting to the existing contexts and help them become constructive decision-makers.

\section{Conflicts of interest}

The authors declare that they have no conflicts of interest.

\section{References}

Abednia, A. (2012). Teachers' professional identity: Contributions of a critical EFL teacher education course in Iran. Teaching and Teacher Education, 28(5), 706-717. https://doi.org/10.1016/j.tate.2012.02.005

Akbari, R. (2008). Postmethod discourse and practice. TESOL Quarterly, 42(4), 641-652. https://doi. org/10.1002/j.1545-7249.2008.tb00152.x

Aneja, G. A. (2016). (Non) native speakered: Rethinking (non) nativeness and teacher identity in TESOL teacher education. TESOL Quarterly, 50(3), 572-596. https://doi.org/10.1002/tesq.315

Beauchamp, C., \& Thomas, L. (2009). Understanding teacher identity: An overview of issues in the literature and implications for teacher education. Cambridge Journal of Education, 39(2), 175-189. https://doi. org/10.1080/03057640902902252

Beijaard, D., Meijer,P.C., \& Verloop, N. (2004). Reconsidering research on teachers' professional identity. Teaching and Teacher Education, 20(2), 107-128. https://doi.org/10.1016/j.tate.2003.07.001

Borg, S. (2003). Teacher cognition in language teaching: A review of research on what language teachers think, know, believe, and do. Language Teaching, 36(2), 81-109. https://doi.org/10.1017/S0261444803001903

Borg, S. (2006). Teacher cognition and language education. Continuum.

Borg, S. (2009). Language teacher cognition. In A. Burns, \& J. C. Richards (Eds.), The Cambridge guide to second language teacher education (pp. 163-170). Cambridge University Press.

Borg, S., \& Al-Busaidi, S. (2012). Learner autonomy: English language teachers' beliefs and practices. ELT Journal, 12(7), 1-45.

Brooks, F. B., \& Darhower, M. A. (2014). It takes a department! A study of the culture of proficiency in three successful foreign language teacher education programs. Foreign Language Annals, 47(4), 592-613. https:// doi.org/10.1111/flan.12118

Bukor, E. (2015). Exploring teacher identity from a holistic perspective: Reconstructing and reconnecting personal and professional selves. Teachers and Teaching, 21(3), 305-327. https://doi.org/10.1080/13540602 .2014 .953818

Burns, A., \& Richards, J. C. (Eds.). (2009). The Cambridge guide to second language teacher education. Cambridge University Press.

Casey, M.A. \& Krueger, R.A. (2000). Focus groups: A practical guide for applied research. Sage publications.

Corbin, J., \& Strauss, A. (2014). Basics of qualitative research: Techniques and procedures for developing grounded theory. Sage publications.

Crookes, G. V. (2015). Redrawing the boundaries on theory, research, and practice concerning language teachers' philosophies and language teacher cognition: Toward a critical perspective. The Modern Language Journal, 99(3), 485-499. https://doi.org/10.1111/modl.12237

Darling-Hammond, L. (2006). Constructing 21st-century teacher education. Journal of Teacher Education, 57(3), 300-314. https://doi.org/10.1177/0022487105285962

Darling-Hammond, L., \& Youngs, P. (2002). Defining "highly qualified teachers": What does "scientifically-based research" actually tell us?. Educational researcher, 31(9), 13-25. https://doi.org/10.3102/0013189X031009013

Day, R. (1993). Models and the knowledge base of second language teacher education. University of Hawai' $i$ working papers in English as a second language, 11(2), 1-13. 
Debreli, E. (2012). Change in beliefs of pre-service teachers about teaching and learning English as a foreign language throughout an undergraduate pre-service teacher training program. Procedia-Social and Behavioral Sciences, 46, 367-373. https://doi.org/10.1016/j.sbspro.2012.05.124

DeWalt, K. M., \& DeWalt, B. R. (2010). Participant observation. In H. Russell Bernard (Ed.), Handbook of methods in cultural anthropology (pp. 259-300). AltaMira Press.

Dörnyei, Z. (2007). Research methods in applied linguistics: Quantitative, qualitative, and mixed methodologies. Oxford University Press.

Eslamdoost, S., King, K. A., \& Tajeddin, Z. (2019). Professional identity conflict and (re) construction among English teachers in Iran. Journal of Language, Identity \& Education, 19(5), 1-15. https://doi.org/10.1080/1534 8458.2019.1676157

Fairley, M. J. (2020). Conceptualizing language teacher education centered on language teacher identity development: A competencies-based approach and practical applications. TESOL Quarterly, 54(4),128. https://doi.org/10.1002/tesq.568

Farrell, T.S.C. (2018). Research on reflective practice in TESOL. Routledge.

Foncha, J. W., Abongdia, J. F. A., \& Adu, E. O. (2015). Challenges encountered by student teachers in teaching English language during teaching practice in East London, South Africa. International Journal of Educational Sciences, 9(2), 127-134. https://doi.org/10.1080/09751122.2015.11890302

Freeman, D. (2002). The hidden side of the work: Teacher knowledge and learning to teach. A perspective from North American educational research on teacher education in English language teaching. Language Teaching, 35(1), 1-13. https://doi.org/10.1017/S0261444801001720

Freeman, D., \& Johnson, K. E. (1998). Reconceptualizing the knowledge base of language teacher education. TESOL Quarterly, 32, 397-417. https://doi.org/10.2307/3588114

Ganji, M., Ketabi, S., \& Shahnazari, M. (2018). English teacher training courses in Iranian private language institutes: Issues and options. Issues in Educational Research, 28(2), 367-384. http://www.iier.org.au/iier28/ ganji-abs.html

Geyer, N. (2008). Reflective practices in foreign language teacher education: A view through micro and macro windows. Foreign Language Annals, 41(4), 627-638. https://doi.org/10.1111/j.1944-9720.2008.tb03321.x

Gholami, J., \& Qurbanzada, I. (2016). Key stakeholders' attitudes towards teacher education programs in TEFL: A case study of Farhangian University in Iran. Journal of Teacher Education for Sustainability, 18(2), 5-20. https:// doi.org/10.1515/jtes-2016-0011

Hedgcock, J. S. (2002). Toward a socioliterate approach to second language teacher education. The Modern Language Journal, 86(3), 299-317. https://doi.org/10.1111/1540-4781.00151

Hennissen, P., Beckers, H., \& Moerkerke, G. (2017). Linking practice to theory in teacher education: A growth in cognitive structures. Teaching and Teacher Education, 63, 314-325. https://doi.org/10.1016/j.tate.2017.01.008

Higgs, L. G. (2013, May 14-17). Theory in educational research and practice in teacher education [Paper presentation]. Annual International Conference of the Bulgarian Comparative Education Society, Plovdiv, Bulgaria.

Huhn, C. (2012). In search of innovation: Research on effective models of foreign language teacher preparation. Foreign Language Annals, 45(1), 163-183. https://doi.org/10.1111/j.1944-9720.2012.01184.x

Johnson, K. E. (2006). The sociocultural turn and its challenges for second language teacher education. TESOL Quarterly, 40(1), 235-257. https://doi.org/10.2307/40264518

Johnson, K. E. (2009). Trends in second language teacher education. In A. Burns, \& J. C. Richards (Eds.), The Cambridge guide to second language teacher education (pp. 20-30). Cambridge University Press.

Johnson, K. E. (2015). Reclaiming the relevance of L2 teacher education. The Modern Language Journal, 99(3), 515-528. https://doi.org/10.1111/modl.12242

Kimmelmann, N., \& Lang, J. (2019). Linkage within teacher education: Cooperative learning of teachers and student teachers. European Journal of Teacher Education, 42(1), 52-64. https://doi.org/10.1080/02619768.20 18.1547376

Korthagen, F. A. (2004). In search of the essence of a good teacher: Towards a more holistic approach in teacher education. Teaching and Teacher Education, 20(1), 77-97. https://doi.org/10.1016/j.tate.2003.10.002

Korthagen, F. (2010). The relationship between theory and practice in teacher education. International encyclopedia of education, 7, 669-675. https://doi.org/10.1016/b978-0-08-044894-7.00638-2

Kumaravadivelu, B. (2001). Toward a postmethod pedagogy. TESOL Quarterly, 35(4), 537-560. https://doi. org $/ 10.2307 / 3588427$

Kumaravadivelu, B. (2008). Understanding language teaching: From method to postmethod. Routledge.

Kumaravadivelu, B. (2012). Language teacher education for a global society. Routledge.

Mattheoudakis, M. (2007). Tracking changes in pre-service EFL teacher beliefs in Greece: A longitudinal 


\section{GIVING VOICE TO THE VOICELESS: PROBING CURRENT ISSUES}

study. Teaching and Teacher Education, 23(8), 1272-1288. https://doi.org/10.1016/j.tate.2006.06.001

Mirhosseini, S. A., \& Khodakarami, S. (2016). Aspects of 'English language education' policies in Iran: 'Our own beliefs' or 'out of who you are'? Journal of Multicultural Discourses, 11(3), 283-299. https://doi.org/10.1080/1 7447143.2016.1217870

Nickel, J., \& Zimmer, J. (2019). Professional identity in graduating teacher candidates. Teaching Education, 30(2), 145-159. https://doi.org/10.1080/10476210.2018.1454898

Paine, L. W. (2019). Missing voices and possible dialogues: Problems and possibilities for teacher education. Teachers and Teaching, 25(6), 684-702. https://doi.org/10.1080/13540602.2019.1643712

Pajares, M. F. (1992). Teachers' beliefs and educational research: Cleaning up a messy construct. Review of Educational Research, 62(3), 307-332. https://doi.org/10.3102/00346543062003307

Phipps, S., \& Borg, S. (2009). Exploring tensions between teachers' grammar teaching beliefs and practices. System, 37(3), 380-390. https://doi.org/10.1016/j.system.2009.03.002

Richards, J. C. (1990). The language teaching matrix. Cambridge University Press.

Richards, J. C. (2002). 30 years of TEFL/TESL: A personal reflection. RELC Journal, 33 (1), 1-35. https://doi. org/10.1177/003368820203300201

Sadeghi, K., \& Richards, J. C. (2016). The idea of English in Iran: An example from Urmia. Journal of Multilingual and Multicultural Development, 37(4), 419-434. https://doi.org/10.1080/01434632.2015.1080714

Safari, P., \& Rashidi, N. (2015). Teacher education beyond transmission: Challenges and opportunities for Iranian teachers of English. Issues in Educational Research, 25(2), 187-203. https://search.informit.com.au/ documentSummary; $\mathrm{dn}=376818708170310$;res=IELHSS

Schepens, A., Aelterman, A., \& Vlerick, P. (2009). Student teachers' professional identity formation: Between being born as a teacher and becoming one. Educational Studies, 35(4), 361-378. https://doi. org/10.1080/03055690802648317

Shenton, A. K. (2004). Strategies for ensuring trustworthiness in qualitative research projects. Education for Information, 22(2), 63-75. https://doi.org/10.3233/EFI-2004-22201

Sjølie,E. (2014). The role of theory in teacher education: Reconsidered from a student teacher perspective. Journal of Curriculum Studies, 46(6), 729-750. https://doi.org/10.1080/00220272.2013.871754

Søreide, G. E. (2006). Narrative construction of teacher identity: Positioning and negotiation. Teachers and Teaching: Theory and Practice, 12(5), 527-547. https://doi.org/10.1080/13540600600832247

Swennen, A., Lunenberg, M., \& Korthagen, F. (2008). Preach what you teach! Teacher educators and congruent teaching. Teachers and Teaching, 14(5-6), 531-542. https://doi.org/10.1080/13540600802571387

Tajik, L., \& Pakzad, K. (2016). Designing a reflective teacher education course and its contribution to ELT teachers' reflectivity. Australian Journal of Teacher Education, 41(9), 58-80. https://doi.org/10.14221/ajte.2016v41n9.4

Tajik, L., Mirhosseini, S. A., \& Ramezani, A. (2019). «Now as a teacher»: Novice teachers reflect on English language teacher education in Iran. The Qualitative Report, 24(6), 1373-1398.

Walkington, J. (2005). Becoming a teacher: Encouraging development of teacher identity through reflective practice.Asia-PacificJournal of TeacherEducation,33(1),53-64.https://doi.org/10.1080/1359866052000341124

Wallace, M. J. (1991). Training foreign language teachers: A reflective approach. Cambridge University Press.

Wilks, J. L., Snow, M., Lasczik, L., \& Bowling, A. (2019). Working towards 'doing it better': Seeking the student voice in teacher education. Australian Journal of Teacher Education, 44(1), 76-92. https://doi.org/10.14221/ ajte.2018v44n1.5

Yangın Ekşi, G., Yılmaz Yakışık, B., Aşık, A., Fişne, F. N., Werbińska, D., \& Cavalheiro, L. (2019). Language teacher trainees' sense of professional agency in practicum: Cases from Turkey, Portugal and Poland. Teachers and Teaching, 25(3), 279-300. https://doi.org/10.1080/13540602.2019.1587404

Zare-ee, A., \& Ghasedi, F. (2014). Professional identity construction issues in becoming an English teacher. Procedia-Social and Behavioral Sciences, 98, 1991-1995. https://doi.org/10.1016/j.sbspro.2014.03.633 


\section{Appendix}

Participants of the study: the details

\begin{tabular}{|c|c|c|c|c|c|c|c|}
\hline No. & Degree level & Code & University & Gender & Age & Teaching Experience & Enrollment Status \\
\hline 1 & \multirow{17}{*}{$\mathrm{BA}$} & BA1 & Private & Female & 23 & 3 years & Full-time \\
\hline 2 & & BA2 & Private & Female & 22 & 1 year & Full-time \\
\hline 3 & & BA3 & Private & Male & 24 & 2 years & Full-time \\
\hline 4 & & BA4 & Private & Female & 24 & 1 year and a half & Full-time \\
\hline 5 & & BA5 & Private & Female & 23 & 1 year & Full-time \\
\hline 6 & & BA6 & Private & Male & 22 & None & Full-time \\
\hline 7 & & BA7 & Private & Female & 22 & None & Full-time \\
\hline 8 & & BA8 & Private & Male & 23 & None & Full-time \\
\hline 9 & & BA9 & Private & Male & 21 & None & Full-time \\
\hline 10 & & BA10 & Public & Male & 24 & 1 year and a half & Full-time \\
\hline 11 & & BA11 & Public & Female & 23 & 4 years & Full-time \\
\hline 12 & & BA12 & Public & Female & 23 & 1 year & Full-time \\
\hline 13 & & BA13 & Public & Male & 24 & 2 years & Full-time \\
\hline 14 & & BA14 & Public & Male & 23 & 3 years & Full-time \\
\hline 15 & & BA15 & Public & Female & 22 & None & Full-time \\
\hline 16 & & BA16 & Public & Female & 21 & None & Full-time \\
\hline 17 & & BA17 & Public & Female & 22 & None & Full-time \\
\hline 18 & \multirow{14}{*}{ MA } & MA18 & Private & Male & 26 & 5 years & Full-time \\
\hline 19 & & MA19 & Private & Female & 28 & 6 years & Full-time \\
\hline 20 & & MA20 & Private & Female & 26 & 4 years & Full-time \\
\hline 21 & & MA21 & Private & Female & 27 & 3 years & Full-time \\
\hline 22 & & MA22 & Private & Female & 27 & 4 years & Full-time \\
\hline 23 & & MA23 & Private & Female & 29 & 7 years & Full-time \\
\hline 24 & & MA24 & Private & Male & 31 & 9 years & Full-time \\
\hline 25 & & MA25 & Public & Male & 29 & 5 years & Full-time \\
\hline 26 & & MA26 & Public & Female & 27 & 3 years & Full-time \\
\hline 27 & & MA27 & Public & Female & 30 & 9 years & Full-time \\
\hline 28 & & MA28 & Public & Female & 26 & 2 years & Full-time \\
\hline 29 & & MA29 & Public & Male & 29 & 5 years & Full-time \\
\hline 30 & & MA30 & Public & Female & 26 & 3 years & Full-time \\
\hline 31 & & MA31 & Public & Male & 28 & 7 years & Full-time \\
\hline 32 & \multirow{10}{*}{$\mathrm{PhD}$} & PhD32 & Private & Female & 34 & 11 years & Full-time \\
\hline 33 & & PhD33 & Private & Male & 32 & 10 years & Full-time \\
\hline 34 & & PhD34 & Private & Female & 38 & 14 years & Full-time \\
\hline 35 & & $\mathrm{PhD} 35$ & Private & Female & 29 & 6 years & Full-time \\
\hline 36 & & PhD36 & Private & Female & 36 & 12 years & Full-time \\
\hline 37 & & PhD37 & Public & Female & 33 & 7 years & Full-time \\
\hline 38 & & $\mathrm{PhD38}$ & Public & Female & 37 & 13 years & Full-time \\
\hline 39 & & PhD39 & Public & Male & 32 & 10 years & Full-time \\
\hline 40 & & $\mathrm{PhD} 40$ & Public & Male & 35 & 12 years & Full-time \\
\hline 41 & & PhD41 & Public & Female & 34 & 9 years & Full-time \\
\hline
\end{tabular}

